\title{
Protoplast culture and plant regeneration of different agronomically important Brassica species and varieties
}

\author{
JÁNOS PAUK*, SÁNDOR FEKETE*, JUHA VILKKI** and SEPPO PULLI** \\ * Cereal Research Institute, POB. 391, \\ H-6701 Szeged, Hungary \\ ** Agricultural Research Centre, Institute of Plant Breeding, \\ $S F-31600$ Jokioinen, Finland
}

\begin{abstract}
Protoplast cultures were prepared from 6-day-old hypocotyls of six spring, seven winter cultivars of Brassica napus L. and one line of Brassica campestris L. The molarity of enzyme solution was raised to $0,714 \mathrm{M}$ mannitol resulting in well manipulable, cytoplasm dense protoplasts. In the protoplast purification procedure density gradient centrifugation was used to minimize physical damage of protoplasts.

Three different protoplast culture systems - (1) liquid, (2) 2nd day embedded, (3) directly embedded in low melting agarose were compared. The two different protoplast embedding techniques resulted in the same efficiency of cell division as the liquid culture method and over this fact the colony browning was avoided. Using protoplast agarose-embedding and culture techniques, healthy calli were obtained for plant regeneration experiments.

Incorporation of silver nitrate into the regeneration medium improved the efficiency of plant regeneration in responsive genotypes and the regeneration was induced in three nonresponsive (without silver nitrate) genotypes, too. The supplement of silver nitrate in regeneration medium was especially advantageous in plant regeneration of $\boldsymbol{B}$. campestris.

Out of fourteen commercial cultivars of Brassica napus and B. campestris, there is only one recalcitrant genotype in obtaining plantlets from protoplast-derived calli.
\end{abstract}

Index words: protoplast isolation, protoplast culture, silver nitrate, plant regeneration, Brassica napus $\mathrm{L}$, Brassica campestris $\mathrm{L}$.

\section{Introduction}

Since several of the most widespread methods of introducing foreign genes into plant cells rely on protoplasts, the establishment of a reproducible protoplast-plant sys- tem is of a crucial importance in any plant species of biotechnological interest.

The first successfull protoplast isolation and plant regeneration experiments have been performed by Wenzel (1973). The Brassica species vary considerably in their ability to 
regenerate plant from protoplast. While the Brassica napus and the Brassica oleracea (BIDNEY et al. 1983, RoberTSON et al. 1984) generally give good results in protoplast regeneration experiments (KARTHA et al. 1974, Li et al. 1982, Glimelius 1984), in case of turnip rape (B. campestris, B. rapa) the plant regeneration from protoplast derived calli remained a sporadic event (Glimelius 1984, ULRICH et al. 1980).

The aim of the present study was to develop a largely genotype independent, efficient plant regeneration procedure for $B$. napus $\mathrm{L}$. and $B$. campestris L. with agronomical importance.

\section{Material and methods}

To extend the protoplast-plant system to different genotypes of agronomic importance various spring and winter type varieties were included in the study. Spring cultivars of Brassica napus L. spp. oleifera cv. Hanna, Kunto, Olga, Omega, Varma, Westar and winter cultivars Arabella, Belinda, Danubia, Darmor, Santana, Újfertödi, Viking were tested. One Brassica campestris L. ssp. oleifera breeding line - Jo. 4001 - was used, too (Table 2). The data were calculated from 2 or 3 independent experiments.

For protoplast isolation, the seeds were surface sterilized with $75 \%$ alcohol for $1-2$ minutes, then immersed in $2 \% \mathrm{NaO}$ ' $\mathrm{Cl}$ with some drops of Tween 80 and continually shaken for 20 minutes followed by a thorough wash in autoclaved sterile distilled water. Sterilized seeds were germinated on a hormonfree MS medium (Murashige and SkoOG 1962) for $5-6$ days in darkness at $28^{\circ} \mathrm{C}$.

The 5-6 cm long hypocotyls were cut into small pieces of about $1.0 \mathrm{~mm}$ and treated for $17-18$ hours (generally overnight) with $1 \%$ Cellulase R-10 and Macerozyme R-10 enzymes dissolved in K3 (Nagy and Maliga 1976) medium. The osmotic pressure of the enzyme mixture was raised to $0.714 \mathrm{M}$ using mannitol as osmotic stabilizer. This treatment resulted in a great number of comparatively small pro- toplasts with dense cytoplasm. The filtration of the isolated protoplasts was omitted to minimize physical damage. The enzyme mixture together with the protoplast and the hypocotyl debris were diluted with W5 salt solution (Menczel et al. 1981) to 5-6 times the original volume and centrifuged for 5 minutes at $120 \mathrm{~g}$. The supernatant was discarded and the protoplasts, mixed with debris, were suspended in 0,6 M sucrose and W5 was layered on the top, then centrifugated at $120 \mathrm{rpm}$ for 5 minutes. The floating protoplasts were collected by Pasteur pipette and washed twice with W5 solution. The isolated protoplasts were cultured in 0,4 M K-75 medium (KAO and Michayluk 1975) modified by Glimelius (1984), at $28^{\circ} \mathrm{C}$ in dark. Protoplasts were cultured at a density of $6 \times 10^{4}$ in three different culture systems: (1) liquid medium, (2) embedded on the 2 nd day from liquid into agarose and (3) embedded into agarose directly after isolation. The embedded cultures were solidified by $0,8 \%$ low melting agarose (Sigma type VII). After about 10 days the liquid and agarose embedded cultures were fed with liquid medium with reduced osmoticum (3\% sucrose). The cell aggregates were ready to plate from the beginning of the third week. The liquid cultures were plated on agar solidified regeneration medium and the agarose blocks were floated in liquid medium before plating. The hormones were decreased to quater strength in the nutrient and floating medium as described by VAmLING and GLimeLIUS (1990).

The plant regeneration was carried out on $\mathrm{K} 3$ medium supplemented with $0.5 \mathrm{mg} / 1 \mathrm{BAP}$, $0,5 \mathrm{mg} / 1 \mathrm{Zeatin}$ and $0,1 \mathrm{mg} / 1 \mathrm{IAA}$ (Nagy and Maliga 1976, Vamling and Glimelius 1990). To increase the efficiency of plant regeneration $5 \mathrm{mg} / \mathrm{l} \mathrm{AgNO}_{3}$ was added to the regeneration medium. Regenerants were grown up with space isolation in different greenhouse chambers.

\section{Results}

In each variety the protoplasts (Fig. 1a) 


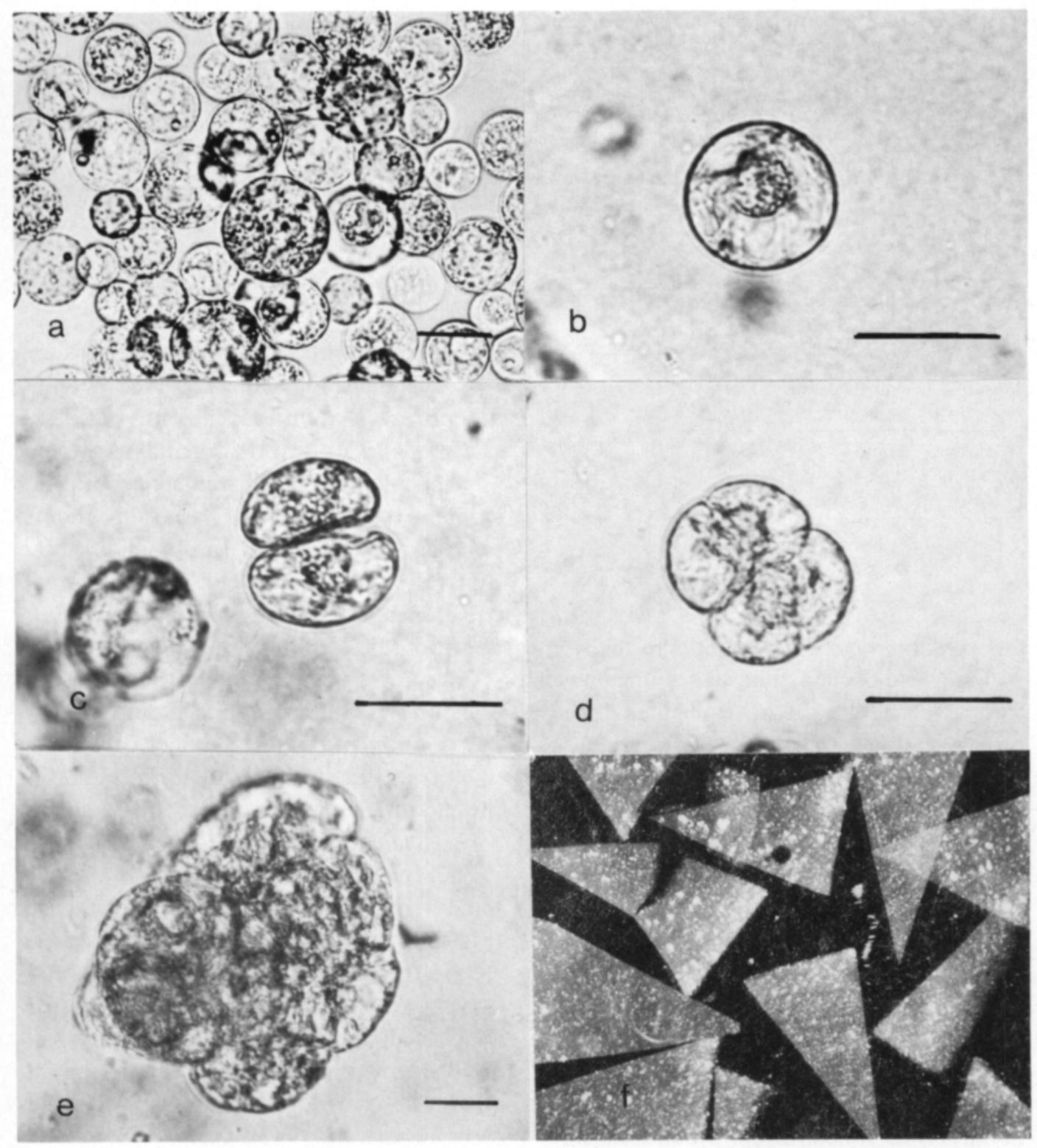

Fig. 1. Development of Brassica protoplast-callus system using agarose embedding technique with 'Varma' cv. a. Freshly-isolated protoplasts collected from the interphase of gradient centrifugation. Bar $=40 \mu \mathrm{m}$. b. Cytoplasmrich protoplast embedded in agarose solidified medium. Bar $=40 \mu \mathrm{m}$. c. Freshly divided protoplast embedded into agarose from liquid medium on the second day of culturing. Bar $=40 \mu \mathrm{m}$. d. Second cell division within 4 days of culturing. Bar $=40 \mu \mathrm{m}$. e. Cell clusters obtained within 40 days of culturing. Bar $=0,1 \mathrm{~mm}$. f. Protoplast-derived colonies of 'Varma' cultivar in agarose-solidified medium and agarose blocks floated in liquid medium. Magnification $=2 \mathrm{x}$.

were isolated from hypocotyl. The relatively high osmotic pressure $(0,714 \mathrm{M})$ results in small, cytoplasm-dense protoplasts. Small, cytoplasm-rich (Fig. 1b) protoplasts were well manipulable during isolation procedure and proved to be excellent for different culture procedures.

The culture methods applied resulted in difference in initiation of cell division at 24hour age (Table 1). Protoplasts cultured in liq- 
Table 1. Percentage of dividing cells using three different culture methods in protoplast cultures of three B. napus cv. The numbers of division (in percent) were counted after 24-, 48- and 96 hours.

\begin{tabular}{llrcc}
\hline Genotype & \multicolumn{1}{c}{$\begin{array}{c}\text { Culture } \\
\text { method* }\end{array}$} & \multicolumn{3}{c}{$\begin{array}{c}\text { Percentage of dividing } \\
\text { cells after }\end{array}$} \\
\cline { 3 - 5 } & & $\begin{array}{c}24 \\
\text { hours }\end{array}$ & $\begin{array}{c}48 \\
\text { hours }\end{array}$ & $\begin{array}{c}96 \\
\text { hours }\end{array}$ \\
\hline \multirow{4}{*}{ Olga } & liquid & 1,1 & 18 & 48 \\
& emb. 2nd d. & 1,0 & 14 & 46 \\
& emb. direct & 0 & 16 & 47 \\
\hline \multirow{4}{*}{ Varma } & liquid & 2,3 & 12 & 51 \\
& emb. 2nd d. & 2,4 & 14 & 53 \\
& emb. direct & 0,1 & 10 & 49 \\
\hline \multirow{3}{*}{ Arabella } & liquid & 0,7 & 9 & 44 \\
& emb. 2nd d. & 0,9 & 7 & 42 \\
& emb. direct & 0 & 7 & 45 \\
\hline
\end{tabular}

* See in Materials and methods

uid medium were able to undergo divisions from the end of the 1st day depending on culture methods. Protoplasts embedded directly after isolation into agarose were capable to divide from the 2 nd day of culturing showing visible divisions at 48th hour (Fig. 1c). The agarose technique seems to be a hindering factor in the starting of cell division, but this hindering effect disappeared on the fourth day of culturing. There was no significant difference in percentage of dividing cells obtained from different varieties using different culture techniques on the fourth day of culturing (Table 1). Each variety produced about the same percentage of divisions on the fourth day (in 96 hours) of subculturing. Second divisions (Fig. 1d) were observed from the third day of subculturing.

Among the varieties, Varma was the most responsive in the efficiency of cell division at the end of the 4th day of culture, but in commencement of microcolony development there was no substantial difference between culture methods regarding the percentage of developed colonies.

Observing of cell division after 96 hours of culturing was easier in agarose embedded cultures because the well-spread cells, protoplastderived colonies in agarose were in fixed po- sitions while in liquid medium the cells were aggregated spontaneously and it was difficult to distinguish between division-derived microcolonies and spontaneous cell groups.

After about ten days in cultures small calli or micro colonies (Fig. 1e) had developed in both culture systems. There was an essential difference between liquid culture technique and agarose solidified culture. In the liquid cultures a brown precipitation started to develop around microcalli from the second week. This phenomenon, observed by other authors as well (SCHENCK and HofFMAN 1979, Glimelius 1984), was detrimental to the subsequent culture work, inhibiting or completely stopping the growth. This harmful phenomenon was not observed in agarose solidified cultures (Fig. 1f) indicating more favourable outcome when using agarose-embedding in Brassica protoplast culture.

Except for one variety - Újfertődi - , every variety in both Brassica napus and campestris formed a higher number of calli for plant regeneration experiments (Table 2). At the end of 2 nd and $3 \mathrm{rd}$ week, the number of formed microcalli varied, depending on individual cultures and genotypes, but no essential differences were found between cultivars.

In most cases white calli with green or greenish morphogene structures (Fig. 2, indicated by arrows) were obtained on the regeneration medium but the efficiency of plant regeneration remained low (Table 3). Initially, only in ten of fourteen Brassica genotypes plant regeneration was successful. The regenerants (Fig. 3) were obtained from green organogenetic centres on the surface of white calli, and generally one or two shoots were obtained from one callus (Fig. 3). Consequently, to test its effect on regeneration, $\mathrm{AgNO}_{3}$ was added to the regeneration medium. In the presence of $5 \mathrm{mg} / \mathrm{AgNO}_{3}$ the regeneration efficiency was substantially increased including multiple shoots (Fig. 4 and 5) in the positive cases. Out of the fourteen Brassica genotypes studied, thirteen gave plantlets with varying numbers of regenerants (Table 3). This modified regeneration procedure - re- 
Table 2. Summary of results in protoplast isolation, culture, callus induction, plant regeneration and source of genotypes used in investigations.

\begin{tabular}{llllll}
\hline $\begin{array}{l}\text { Species, variety and } \\
\text { source }\end{array}$ & Life form & Protoplast & & Plant regene- \\
\cline { 2 - 4 } & & isolation & culture & derived calli & ration \\
\hline
\end{tabular}

\section{B. napus}

$\begin{array}{lrc}\text { Olga } & \text { S } & \text { spring } \\ \text { Varma } & \text { SF } & " \\ \text { Westar } & \text { CAN } & " \\ \text { Kunto } & \text { S } & " \\ \text { Hanna } & \text { S } & " \\ \text { Omega } & \text { S } & "\end{array}$

Viking

Arabella

Darmor

Santana

Danubia

Belinda

Újfertödi

DK winter

D n

F n

D n

B. campestris
Jo. 4001
SF
spring

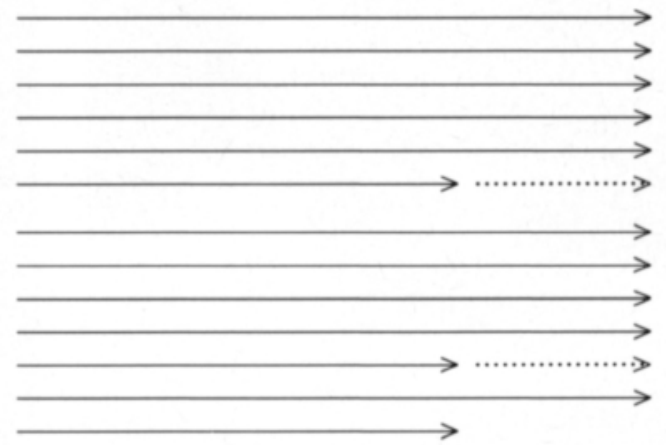

$\rightarrow$ without silver nitrate in regeneration medium

$\rightarrow$ with silver nitrate in regeneration medium

generation medium supplemented with $\mathrm{AgNO}_{3}$ - has a particularly advantageous effect on regeneration of $B$. campestris which has been

Table 3. The effect of silvernitrate $\left(\mathrm{AgNO}_{3}\right)$ on plant regeneration from protoplast derived calli of $B$. napus and B. campestris varieties.

\begin{tabular}{lrrr}
\hline $\begin{array}{l}\text { Name of genotype } \\
\text { and life form }\end{array}$ & \multicolumn{2}{c}{$\begin{array}{c}\text { \% of shoot regenerating } \\
\text { calli }\end{array}$} \\
\cline { 3 - 4 } & & $-\mathrm{AgNO}_{3} \quad+\mathrm{AgNO}_{3}$ \\
\hline B. napus & & 24 & 41 \\
Olga & s. & 31 & 39 \\
Varma & s. & 19 & 33 \\
Westar & s. & 11 & 29 \\
Kunto & s. & 9 & 19 \\
Hanna & s. & 0 & 4 \\
Omega & s. & 9 & 23 \\
Viking & $* *$ w. & 10 & 17 \\
Arabella & w. & 4 & 14 \\
Darmor & w. & 6 & 10 \\
Santana & w. & 0 & 8 \\
Danubia & w. & 2 & 6 \\
Belinda & w. & 0 & 0 \\
Újfertödi & w. & & \\
B. campestris & & 0 & 22 \\
Jo. 4001 & s. & & \\
\hline
\end{tabular}

$* \mathrm{~s}=$ spring, $* * \mathrm{w}=$ winter

Regeneration without $\mathrm{AgNO}_{3}(-)$ with $\mathrm{AgNO}_{3}(+)$ known to respond poorly to in vitro manipulation.

The regenerated plantlets were transferred to $\mathrm{K} 3$ medium without $\mathrm{AgNO}_{3}$ which allowed the plantlets to develop rapidly.

\section{Discussion}

The molarity of enzyme solution was raised from 0,4 M sucrose suggested by Glimelius (1984) and V AMLING and Glimelius (1990) to

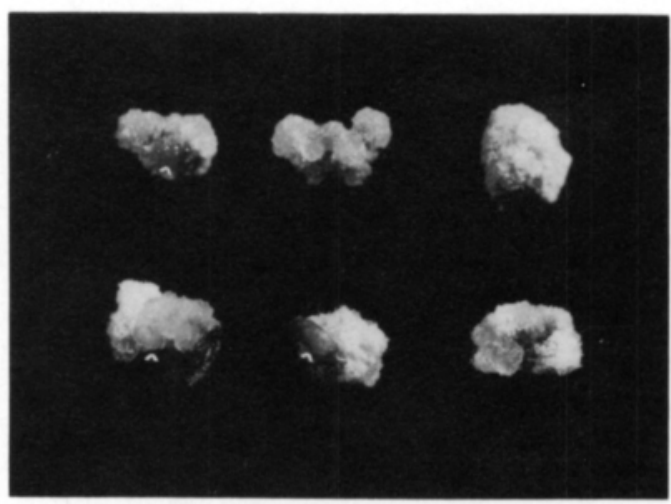

Fig. 2. Protoplast-derived calli with morphogene structure on their surface (arrows) on plant regeneration medium without silver nitrate. 


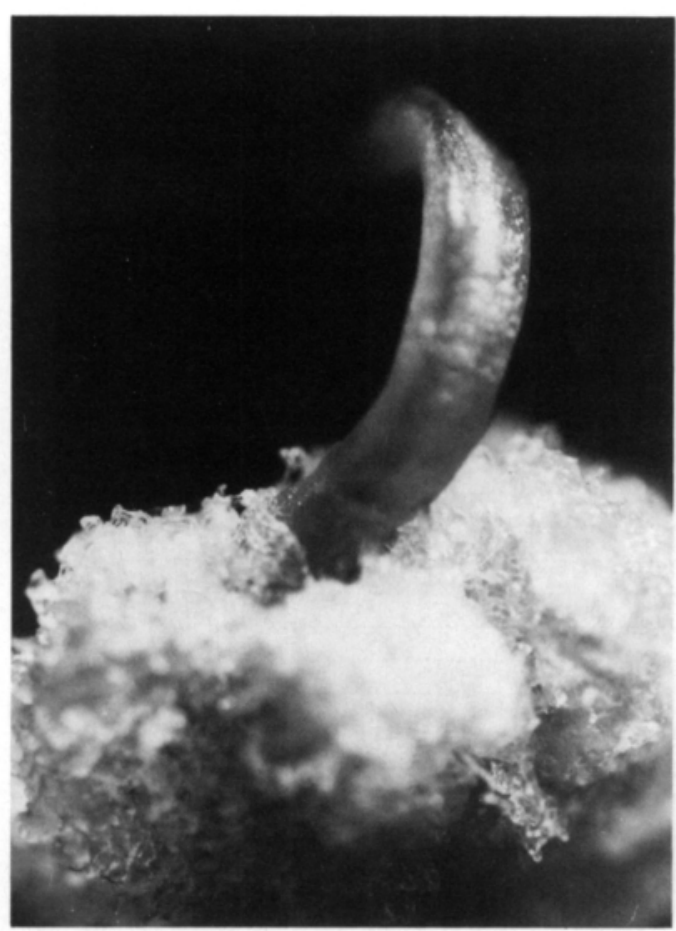

Fig. 3. Typical rapeseed white callus with one shoot on regeneration medium without silver nitrate.

0,714 M mannitol. We thus used higher molarity as KoHLENBACH et al. (1982) who used 0,55 $\mathrm{M}$ and 0,65 $\mathrm{M}$ mannitol for leaf and stem embryo protoplast isolation, respectively. EAPEN et al. (1989) obtained good results using 0,6 M mannitol in enzyme solution in mesophyll protoplast isolation of Brassica

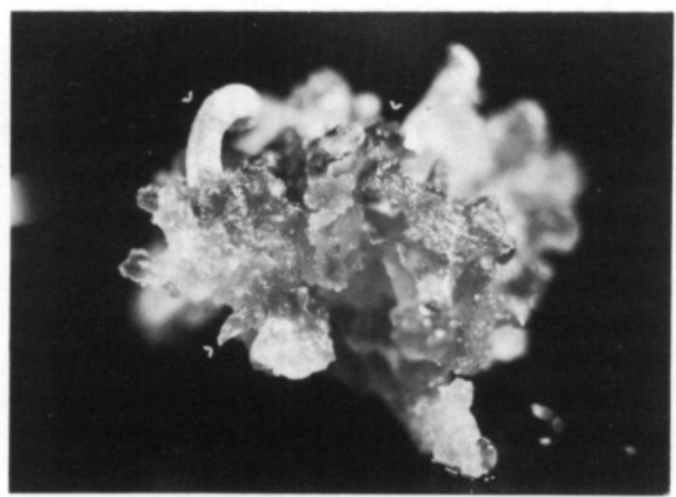

Fig. 4. Well differentiated green protoplast-derived callus with multiple shoot primordia (arrows) on regeneration medium supplemented with $5 \mathrm{mg} / 1 \mathrm{AgNO}_{3}$.

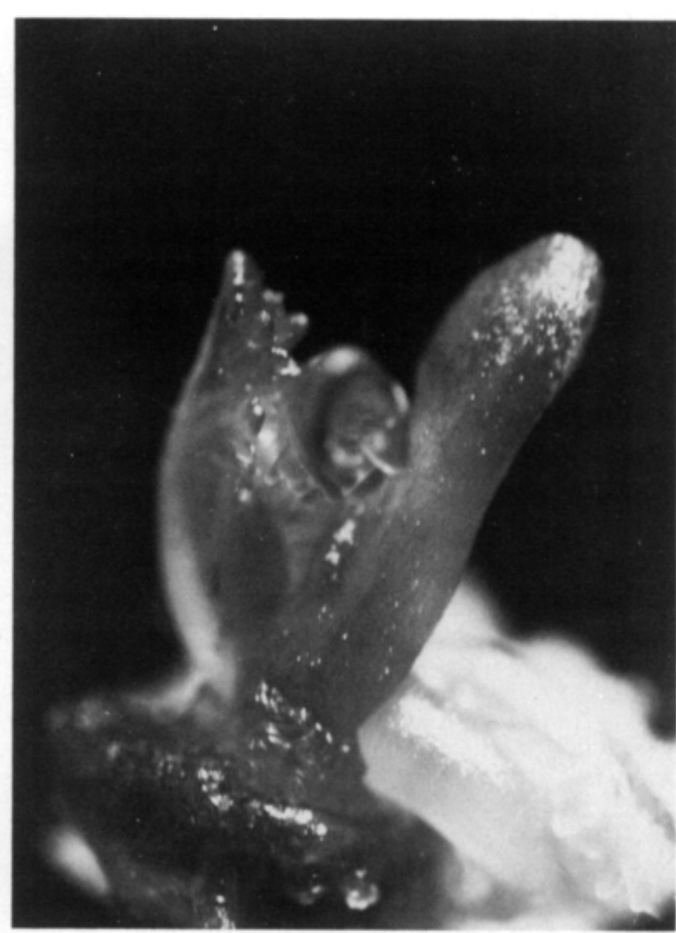

Fig. 5. One shootlet on surface of green callus developing on $\mathrm{AgNO}_{3}$ supplemented regeneration medium.

juncea. The cytoplasm dense small protoplasts proved to be well manipulable during isolation procedure. They will be an essential advantage in direct protoplast transformation experiments where protoplasts are manipulated - washing etc. - several times.

The agarose embedding culture technique developed by SHILlito et al. (1983) has proven to be a successful method in Brassica also. Our results confirmed the applicability of the embedded protoplast culture technique (directly or on the 2nd day of subculturing) which produced the same division results as the liquid culture method (basic culture method) published for Brassica protoplast culture (Bidney et al. 1983, Glimelius 1984, Jourdan et al. 1989, Loudon et al. 1989). This technique has been already used for 2-3- week old colony embedding by VAMLING and GLIMELIUS (1990) resulting in a good culture practice, but our results (early embedding after isolation) show other advantages over this culture technique, too. The colony browning, 
widely reported to be a feature of Brassica protoplast culture (XU et al. 1982, Glimelius 1984, Loudon et al. 1989) was prevented and healthy calli were induced for plant regeneration experiments.

One of the noticeable features of this study is the wide range of responses observed (Table 2). These results show, in accordance with other studies (Jourdan and EARLE 1989, LouDON et al. 1989) that various Brassica varieties of great economic importance can be successfully regenerated from protoplasts. There was only one (Újfertődi) out of the fourteen varieties tested that failed to produce plantlets.

Incorporation of silver nitrate $(5 \mathrm{mg} / \mathrm{l})$ into the regeneration medium improved the efficiency of plant regeneration. With the introduction of $\mathrm{AgNO}_{3}$ three of the examined varieties became responsive in regeneration experiments (Table 3) and regeneration was more efficient in each variety. There is only one recalcitrant genotype - Újfertődi - in our experiments (Table 2 and 3). In agreement with our results, the positive effect of $\mathrm{AgNO}_{3}$ on the induction of plant regeneration has been recently published by other authors as well (Lentini et al. 1988, Songstad et al. 1988) in Brassica and in other crop plants (Purnhauser et al. 1987).

Our results support the findings of PURNHAUSER et al. (1987) and Williams et al. (1990) that $\mathrm{AgNO}_{3}$ has the most favourable effect on plant regeneration when applied at a later stage of callus development (when morphogene zones had already been formed) rather than right from the beginning of callus induction.

Acknowledgements. The authors are thankful to Miss Outi Manninen, Mrs. Maija-Liisa Penttilä, Mrs. Ildikó D. Bartók, for their skilful assistance and Mr. B. Dusha and Mr. B. Kármán in preparing the photographic material. They also wish to thank Mr. L. Nagy for kindly supplying one part of seed material. This work was supported by J. Pauk's 6-month fellowship in Finland.

\section{References}

Bidney, D.L., Shepard, J.F., Kaleikau, E. 1983. Regeneration of plants from mesophylle protoplasts of Brassica oleracea. Protoplasma 117: 89-92.

Eapen, S., Abraham, V., Gerdemann, M., Schieder, O. 1989. Direct somatic embryogenesis, plant regeneration and evaluation of plants obtained from mesophyll protoplasts of Brassica juncea. Annals of Botany 63, $369-372$.

Glimelius, K. 1984. High growth rate and regeneration capacity of hypocotyl protoplast in some Brassicaceae. Physiol. Plant. 61: 38-44.

Jourdan, P.S. - EARLE, E.-D. 1989. Genotypic variability in the frequency of plant regeneration from leaf protoplasts of four Brassica spp. and of Raphanus sativus. J. Amer. Soc. Hort. Sci. 114 (2): 343-349.

KaO, K.N. - MichayluK, M.R. 1975. Nutritional requirements for growth of Vicia hajastana cells and protoplasts at very low population density in liquid media. Planta 126: 105-110.

Kartha, K.K. - Michayluk, M.R. - KaO, K.N. Gamborg, O.L. - Constable, F. 1974. Callus formation and plant regeneration from mesophyll protoplast of rape plants (Brassica napus cv. Zephir) Plant Sci. Lett. 3: 265-271.
Kohlenbach, H.W., Wenzel, G., Hoffmann, F. 1982. Regeneration of Brassica napus plantlets in cultures from isolated protoplasts of haploid stem embryos as compared with leaf protoplasts. Z. Pflanzenphysiol. Bd. 105. S. 131-142.

Lentini, Z. - Mursell, M.A. - Mutschler, M.A. EARLE, E.D. 1988. Ethylen generation and reversal of ethylene effects during development in vitro of rapidcycling Brassica campestris L. Plant Sci. 54: 75-81.

Ll, L.C. - Kohlenbach, H.W. 1982. Somatic embryogenesis in quite a direct way in cultures of mesophyll protoplasts of Brassica napus L. Plant Cell Rep. 1: 209-211.

Loudon, P.T. - Nelson, R.S. - Ingram, D.S. 1989. Studies of protoplast culture and plant regeneration from commercial and rapid-cycling Brassica species. Plant Cell Tiss. Org. Cult. 19: 213-224.

Murashige, T. - Skoog, F. 1962. A revised medium for rapid growth and bioassays with tobacco tissue cultures. Physiol. Plantarum 15: 473-497.

Nagy, J. - Malıga, P. 1976. Callus induction and plant regeneration from mesophyll protoplasts of Nicotiana silvestris. Z. Pflanzenphysiol. 78: 453-455.

Purnhauser, L. - Medgyesi, L. - Czako, M. - Dix, 
P.J. - Márton, L. 1987. Stimulation of shoot regeneration in Triticum aestivum and Nicotiana plumbaginifolia Viv. tissue culture using the ethylen inhibitor $\mathrm{AgNO}_{3}$ Plant Cell Rep. 6: 1-4.

Robertson, D. - Earle, E.D. - Mutschler, M.A. 1984. Enhanced rates of plant regeneration from protoplasts of cultivar Green Comet Broccoli Brassica oleracea. Plant Physiol. 75: 134.

Schenk, H.R., Hoffmann, F. 1979. Callus and root regeneration from mesophyll protoplasts of basic Brassica species: $\boldsymbol{B}$. campestris, $\boldsymbol{B}$. oleracea and $\boldsymbol{B}$. nigrra. Z. Pflanzenzüchtg. 82: 354-360.

Shillito, R.D., Paszkowski, J., Potrikus, I. 1983. Agarose plating and bead type technique enable and stimulate development of protoplast-derived colonies in a number of plant.

Songstad, D.D. - Duncan, D.R. - Widholm, J. M. 1988. Effect of 1-aminocyclopropane-1-carboxylic acid, silver nitrate and norbornadiene on plant regeneration. Plant Cell Rep. 7: 262-265.

\section{SELOSTUS}

\section{Maataloudelle tärkeiden \\ Brassica-lajien protoplastien viljely ja kasvien regenerointi}

\author{
János Pauk*, Sándor Fekete*, Juha Vilkki** \\ and Seppo Pulli** \\ * Cereal Research Institute, Pob. 391, \\ H-6701 Szeged, Hungary \\ ** Agricultural Research Centre, \\ Institute of Plant Breeding, \\ SF-31600 Jokioinen, Finland
}

Tutkimuksessa eristettiin protoplasteja kolmentoista rapsilajikkeen (Brassica napus) ja yhden kevätrypsilinjan (B. campestris) 6 vrk:n ikäisistä hypokotyyleistä.

Protoplastien eristyksessä käytettiin tavanomaista korkeampimolaarista entsyymiliuosta $(0.714 \mathrm{M}$ mannitoli). Näin saatiin pieniä, kestäviä, runsaasti solulimaa sisältăviă protoplasteja. Protoplastien vaurioitumisen vălttămiseksi eristyksessä käytettiin tiheysgradienttisentrifugointia.

Tutkimuksessa verrattiin kolmea eri protoplastiviljelymenetelmää: 1) nesteviljely, 2) maljaus agaroosiin toi-
Ulrich, T.H. - ChowdhuRY, J.B. - Wildholm, J.M. 1980. Callus and root formation from mesophyll protoplasts of Brassica rapa. Plant Sci. Lett. 19: 347 -354 .

Vamling, K., Glimelius, K. 1990. Regeneration of plants from protoplasts of oilseed Brassica crops. In: BAJAJ (ed.): Biotechnology in Agriculture and Forestry. Vol. 10. 385-417. Springer-Verlag, Heidelberg.

Wenzel, G. 1973. Isolation of leaf protoplasts from haploid plants of petunia, rape and rye. Z. Pflanzenzüch. 69: 58-61.

Williams, J. - Pink, D.A.C. - Biddington, N.L. 1990. Effect of silver nitrate on long-term culture and regeneration of callus from Brassica oleracea var. gemmifera. Plant Cell Tissue Org. Cult. 21: 61-66.

Xu, Z.H., DaveY, M.R., Cocking, E.C. 1982. Plant regeneration from root protoplasts of Brassica. Plant Sci. Lett. 24: 117-121.

Ms received June 9, 1991 sena viljelypäivänä, 3) suora maljaus agaroosiin. Agaroosiviljelmissä solut jakautuivat yhtă aktiivisesti kuin nesteviljelyssä, lisăksi vältyttiin solukolonioiden ruskettumiselta.

Hopeanitraatin $\left(\mathrm{AgNO}_{3}\right)$ käyttő regeneraatioalustassa $(5 \mathrm{mg} / \mathrm{l})$ lisäsi kalluksesta muodostuvien versojen mäărảă niillă 10 lajikkeella, joilla havaittiin vähäistä regeneraatiota jo ilman hopeanitraattia. Kolmella lajikkeella regeneraatio onnistui ainoastaan silloin kuin regeneraatioalustassa oli hopeanitraattia. Erityisen suotuisa vaikutus hopeanitraattilisäyksellă oli kevătrypsin regeneraatioon. 